\title{
ZIMA I ROMANTYCY
}

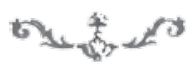

$\mathrm{D}$ LACZEGo zima?' ${ }^{1}$ Przede wszystkim dlatego, że z racji trudnych warunków atmosferycznych zmusza ludzi do obrony, czyli dostosowania do nich technicznych udogodnień. Jest to przeciwieństwo tropikalnego raju, gdzie panuje wieczne lato, a pokarm wisi na drzewie. Poza tym nie ma jednakowej zimy w Europie - zachodnie jej krańce różnią się od północno-wschodnich diametralnie, co przekłada się na odmienność obyczajów i kultury materialnej w poszczególnych rejonach. Na tej podstawie filozofowie i pisarze - od Monteskiusza poczynając, snuli daleko idące uogólnienia na temat charakterów nacji zamieszkujących w rozmaitych regionach naszego kontynentu. Tworzone w ten sposób stereotypy pozwalały na ekstrapolację zachowań w konkretnych warunkach klimatycznych na cechy osobowości żyjących tam ludzi, czego przykładem jest mocno utrwalony obraz ekstrawertycznego południowca i introwertycznego, melancholijnego mieszkańca Północy. Moim celem wszakże nie jest rozważanie tych po wielokroć dyskutowanych kwestii, a jedynie sformułowanie kilku uwag na tematy zimowe związane z polskim romantyzmem. Właśnie polskim, ponieważ zimy nie da się omawiać niezależnie od geografii, która decyduje o randze tego tematu zarówno w życiu, jak i literaturze danej zbiorowości.

Dziewiętnastowieczna zima zachodnioeuropejska, pomijając tereny górskie, była niedługa, epizodyczna, mokra, wilgotna, ze sporadycznymi mrozami czy śniegiem. Problem mieszkańców stanowił chłód w domach i bajora roz-

1 Zob. F. Walter, Hiver. Histoire d'une saison, Paris 2014 (rozdz. Pourquoi l'hiver?). 
puszczonego śniegu na ulicach, utrudniające bądź chwilami uniemożliwiające komunikację. Podczas krótkotrwałych śnieżyc zdarzało się, że powozy grzęzły w zaspach na zaśnieżonej drodze. Sań praktycznie w powszechnym transporcie nie używano. Sezon ten nie cieszył się szczególną popularnością wśród poetów i pisarzy².

Na przeciwległym biegunie sytuuje się zima rosyjska. Długa, mroźna, śnieżna, obejmująca rozległe równinne obszary północno-wschodniej Europy po krańce azjatyckie i Kamczatkę. Od czasów reform Piotra I, zmierzających do westernizacji i sekularyzacji kraju, nastąpiło w ciągu XVIII wieku przeorientowanie rosyjskiej samoświadomości ze wschodniej, prawosławnej - na północną, wyrażającą prężną młodość cywilizacyjną w starej Europie. Zima stała się rosyjską „marką", jak byśmy dziś powiedzieli, wokół której krystalizowała się nowa tożsamość narodowa. Znalazło to swoje odzwierciedlenie w literaturze, w której tematy zimowe pojawiały się często zarówno u poetów doby Oświecenia, jak i romantyków, zwłaszcza Aleksandra Puszkina i Piotra Wiaziemskiego. Z zimą kojarzono swojskość, młodość, radość, świeżość, piękno krajobrazu, zabawy na śniegu i lodzie, szybkie podróże saniami. Zimowe zwycięstwo nad Napoleonem w 1812 roku jeszcze bardziej wzmocniło pozytywne konotacje związane z tą porą roku. Dopiero w późniejszych latach romantycy rosyjscy zaczęli zauważać również ponure aspekty zimna, mrozu i zamieci³.

Polska znalazła się pomiędzy tymi dwoma biegunami. Tereny na wschód od Wisły, a jeszcze bardziej Bugu, miały zimy nieco podobne do rosyjskiej, ale krótsze, mniej mroźne, nieco kapryśne. Im bardziej na zachód, tym bliżej do europejskich warunków pogodowych. Polska zima rzadko bywała obecna w naszej romantycznej literaturze, a jeśli, to bardziej jako dalekie tło niż temat główny. Nie angażowała emocji, nie nadawano jej szczególnych symbolicznych znaczeń. Na przykład w Marii Antoniego Malczewskiego czy w Kuliku Juliusza Słowackiego, gdzie mamy do czynienia z jazdą saniami, nawet śnieg się nie pojawia. Cudzoziemiec nieznający realiów z trudem by się domyślił, że chodzi o porę zimową. Do wyjątków należy Zima miejska Adama Mickiewicza, Noc w Zofiówce Seweryna Goszczyńskiego oraz Słowackiego zimowy epizod własnej kontynuacji Pana Tadeusza. Oczywiście nieco inaczej rzecz się ma w literaturze pamiętnikarskiej czy krajoznawczej, niemniej i tam zima specjalnych skojarzeń nie budzi - po prostu jest.

Nieokreśloność naszej zimy sprawia, że nie jest ona punktem odniesienia dla cywilizacyjnych porównań, jakie Polacy czynią podczas zagranicznych wojaży. Ich wyobraźnia rozpięta jest między Europą a Rosją. Julian Ursyn

2 Zob. tamże (rozdz. Résister), s. 193 i n.

3 Zob. O. Boele, The North in Russian Romantic Literature, Amsterdam-Atlanta 1996. 
Niemcewicz, który stan pogody zapisywał w dzienniku przez kilkadziesiąt lat, podczas paryskiej emigracji takie właśnie typowe uwagi odnotował 5 i 6 stycznia 1835 roku:

Mróz, acz nie dochodzący trzech stopni, żywo doskwiera, nie było takiej okrutnej zimy: nie ma pieców, próżno palić na kominkach, gdy wśród brązów, alabastrów, porcelan wszędzie wieje. [...] Rano i w nocy była skala pięciu gradusów mrozu. Wieczór i w nocy zaczęło tajać, a rano błoto. Moskale śmieją się z takiej zimy. Póki sucho, poszedłem piechotą odwiedzić poetę Mickiewicza. ${ }^{4}$

Kilka lat wcześniej podobne przygody z zimnem w Rzymie stały się udziałem Adama Mickiewicza i Antoniego Edwarda Odyńca. Kiedy przyjechali tam w listopadzie, nie było co prawda śniegu, ale deszcz i ziąb. Pokoje hotelowe $\mathrm{z}$ wysokimi oknami i kamienną posadzką, ze słabym ogniem w kominku, były mocno niedogrzane. „Chłód i wilgoć jak u nas w lodowni, oddech z ust jak dym od cygara" ciepła do księżnej Zinaidy Wołkońskiej, która - niezadowolona z włoskich systemów ogrzewania - jeden z pokojów swojej rzymskiej willi zaopatrzyła w rosyjski piec kaflowy, specjalnie sprowadzony morzem. Na tym jej troska o polskich przyjaciół się nie skończyła - posłała im do hotelu worki z wojłoku do opatulenia nóg i włoską karbonellę - żelazną tacę na nóżkach, gdzie umieszczało się rozżarzone węgle. Owa karbonella mało nie przyprawiła o śmierć naszych wędrowców, którzy grzali się przy niej w zamkniętym pokoju i zatruli czadem. Uratowała ich wizyta księdza Stanisława Parczewskiego ${ }^{6}$.

Warszawska zima nie była taka łagodna jak rzymska, jednak przybyły z Wilna Onufry Pietraszkiewicz także doczekał się tu niezwykłego zimna w mieszkaniu nieprzystosowanym z kolei do mrozów dwucyfrowych. W liście do Tomasza Zana żartobliwie wypowiadał się o wspólnym wileńskim koledze:

Gdybyś go był na zimę do mojej zamknął izby, której ściany z muru pruskiego dobrym były cieplika przewodnikiem, a piec raz się ogrzewał, nie pomyśliłby on o paskach i owszem robiłby doświadczenia z kryształami i przekonałby się, że woda, stojąc nawet przy ogrzanym piecu, krzepła, gdy było - 19. Nie dziw więc, że w Onufrze ognie przystygły, zwłaszcza że musiał się osłaniać płaszczem, który [...] pamięta rewolucją 1812, a którego podszewka rozszarpaną na sztuki Polskę w drobnym jej na okręgi, powiaty i parafie podziale wystawia. Boże Narodzenie było mroźne, siedzieć przy kominie najdogodniej; ale któż się osiedzi, kiedy woda krzepnie??

4 J.U. Niemcewicz, Dzienniki 1835-1836, oprac. I. Rusinowa, Warszawa 2005, s. 14-15.

5 A.E. Odyniec, Listy z podróży, oprac. M. Toporowski, wstęp M. Dernałowicz, Warszawa 1961, t. 2, s. 9.

6 Tamże, s. 110-111.

7 CCCV. Pietraszkiewicz do T. Zana [14/16 grudnia 1820, Warszawa], w: Korespondencja filomatów 1815-1823, wyd. J. Czubek, t. 3: 1820-1821, Kraków 1913, s. 81-82. 
Jak z tego widać, podróż w kierunku zachodnim oznaczała cieplejsze powietrze na dworze, za to zimniejsze, nieprzygotowane do niespodziewanego chłodu wnętrza domów.

Wyjątkowo ostra zima dotknęła całą Europę w pamiętnym 1830 roku, obserwował ją w Warszawie Niemcewicz:

Już trzy miesiące, dzisiaj 5 lutego, jak trwają nieprzerwane mrozy i pamiętam tak tęgie, bo do $22^{\circ}$ dochodzące, ale nigdy tak nieprzerwanie ciągłych. Co za niedola dla ludzi ubogich. Jakoż ustawicznie znajdują ich pomarzłych na ulicach, gdyż nikomu nie wolno przyjąć nieszczęśliwego na noc bez pozwolenia policji; nim się to otrzyma, już biedny leży skościały. Lecz i majętniejsi cierpią już to wysoką ceną drzewa, już niesposobnością, nawet ogrzania się. Co za męka. Od trzech miesięcy, choć w opalonym pokoju, wstawać z ziębłymi rękami i nosem, siadać do pracy i nie móc zmarzłymi palcami pióra utrzymać, siedzieć, chodzić, zawsze drżeć od zimna; niechże mi uczeni wytłumaczą, skąd to nadzwyczajne ciągłe zimno, gdyż: nie tylko u nas, ale i w południowych krajach również to zimno dojmuje; we Francji dochodzi 19 stopni, W Hiszpanii 13, we Włoszech 14. Rzeki Po, Arno i Ebro zamarzły; wszędzie ludzie i bydło i ptactwo ginie, a wilki rozdzierają podróżnych. ${ }^{8}$

To, co na zachód od Rosji było zdarzającym się raz na ileś lat klimatycznym ewenementem, tam należało do zimowej normy.

Różnica między zimą zachodnioeuropejską i rosyjską jeszcze bardziej niż w domach widoczna była na zewnątrz, czyli na drogach, traktach, ulicach - zarówno w zakresie infrastruktury, jak i środków transportu. Europejskie drogi, gładkie i wygodne, kłopoty podróżnym sprawiały właśnie zimą - śnieg nie utrzymywał się tam długo, a rozpuszczony zalegał w postaci wody i błota. W Rosji odwrotnie - jedyne porządne szlaki komunikacyjne istniały tam, gdzie potrzebował ich car i jego urzędnicy, pozostałe, zwłaszcza prowincjonalne, nadawały się do jazdy przede wszystkim zimą, gdyż pozbawione śniegu stawały się wyboiste, dziurawe, błotne, z uskokami i innymi niespodziankami tego rodzaju. Książę Wiaziemski, poeta i przyjaciel Puszkina (także wieloletni znajomy Mickiewicza), który z racji częstych podróży stał się drogowym ekspertem, wielokrotnie w wierszach opisywał swoje wrażenia: „co krok to dziura, mulda, błoto lub wyrwa”. Dopiero mróz i śnieg utwardzał i wygładzał nawierzchnię i przez cały wielomiesięczny sezon zimowy jazda stawała się przyjemnością. Opiewał ją Puszkin, porównując gładkość drogi do „bezmyślnego toku wierszy modnej pieśni”. Saniami można było mknąć z szybkością nieznaną zaprzęgom kołowym, nic więc dziwnego, że Rosjanie cenili swoją zimę, a na europejską spoglądali z politowaniem. Wiaziemski na widok sań w Dreźnie pisał:

Сани здесь - подобной дряни

Не видал я на веку;

8 J.U. Niemcewicz, Pamiętniki z 1830-1831 roku, wyd. M.A. Kurpiel, Kraków 1909, s. 2. 
Стыдно сесть в чужие сани

Коренному русаку. ${ }^{9}$

W Rzymie sań w ogóle nie znano, toteż Polacy postanowili je zrobić, co odnotował Odyniec podczas wspomnianego ataku zimy w Rzymie:

Pan Potocki Artur na wieczorze u siebie mówił do kilku signorów rzymskich, że kazał już robić sanki, w których chce odbyć szlichtadę po Rzymie i jak w triumfie wjechawszy na Kapitol, tam je jako trofeum na pamiątkę zostawić. Wprawdzie jeden z tych panów zrobił mu uwagę, że będzie musiał chyba, jak niegdyś Ossoliński, dosypywać do śniegu miałko tłuczonego cukru, aby polskiej fantazji dogodzić, ale gdyby on miał istotnie ten zamiar, a sanki były już na dzisiaj gotowe, to by się i bez tego ekspensu obeszło. Śnieg na ulicy naszej jest głęboki po kostki. ${ }^{10}$

W Polsce zimowa komunikacja - podobnie jak sama zima - była czymś pośrednim między Rosją a Europą. Śniegu i mrozu, nieraz długotrwałego, nie dało się zignorować, pojazdy musiały być dostosowane - niemniej kaprysy pogody sprawiały, iż nawet w krótkim czasie podróżujący mógł być narażony na nieprzewidziane kłopoty. Jazda saniami po śniegu mogła zakończyć się w rowie pełnym wody, jazda na kołach po grudzie - zaryciem w zaspie - przy nagłej zamieci. Szczegółowe opisy zimowych peregrynacji po Litwie, Polesiu i Wołyniu pozostawiła Ewa Felińska w swoich pamiętnikach. Trudności w doborze odpowiedniego ekwipunku dawało się odczuć zwłaszcza na początku i na końcu zimy. O jednej takiej przejażdżce w sąsiedztwo pisała Felińska:

Droga była niedobra, ani sanna, ani kołowa, mało śniegu, więcej grudy; ekwipaże były rozmaite. Kto nie żałował koni, jechał sankami, ale więcej było takich, co się kół trzymało, do rzędu tych ostatnich należałyśmy i ja i kuzynki [...]. Po obiedzie zeszło przyjemnie, a ku wieczorowi mieliśmy wyjeżdżać, kiedy śnieg gęsty zacząl padać $z$ wielkim ukontentowaniem i triumfem tych, co jechali sankami. Triumf jednak nie był długi, bo przy gęstym śniegu zerwał się wiatr silny i ostry, który ochwytując i unosząc w powietrze wiry śniegu, zrobił zamieć taką, że światu na kilka łokci przed sobą, widno nie było. ${ }^{11}$

W rezultacie goście musieli przenocować, a nazajutrz warunki jazdy w sypkim, głębokim śniegu wymagały odmiennej organizacji powrotnej podróży:

Otóż wyjeżdżamy. Szereg sanek i kołowych ekwipażów stoi przed gankiem; sanki idą poprzód, aby ucierać drogę, za nimi leksze powozy kołowe, a my, kobiety na ostatku, aby mieć przed sobą drogę trochę utartą. ${ }^{12}$

9 P. Wiaziemski, Масленица на чужой стороне [Zapusty na obczyźnie] (1853); cyt. za: O. Boele, dz. cyt., s. 108: „Czegoś tak marnego, jak tutejsze sanie, w życiu nie widziałem; / prawdziwemu Rosjaninowi wstyd siadać do obcych sań" (tłum. - M.Z.).

10 A.E. Odyniec, dz. cyt., s. 101.

11 E. Felińska, Pamiętniki z życia, Seria 2, t. 1, Wilno 1858, s. 10-11.

12 Tamże, s. 16. 
Od szerokości „utartej”, czyli przetartej drogi zależał też sposób zaprzęgania koni. Na przykład w okolicach Mińska, jak wspomina pamiętnikarka, gospodarze najczęściej jeździli jednokonnymi sankami, toteż i większe ekwipaże musiały się do tych ich śladów stosować: „w takim razie - pisała - zaprzęgają kilka koni, ale nie w porącz, tylko koń przed koń po jednemu, choćby ich sześć przyszło zaprząc. Taką jazdę technicznym wyrazem nazywają: jechać szydłem" ${ }^{13}$.

Podobnie jak w Rosji - także na Litwie, a zwłaszcza na bagnistym Polesiu, istniały nieprzejezdne o innych porach roku tak zwane „zimowe gościńce” - czyli szlaki wiodące znacznymi nieraz skrótami przez rozmaite mokradła i rozlewiska. Felińska opisuje swoją i męża odyseję podróżniczą po takiej drodze przez pińskie błota z Litwy na Wołyń u schyłku zimy. Zaryzykowali ten skrót, do pewnego momentu udawało się jechać po mokrym śniegu i zlodowaciałym podłożu, w końcu sanie na dobre utkwiły w bajorze i trzeba je było wyciągać wołami z pobliskiej wsi ${ }^{14}$.

Zimą łatwiejsze były też przeprawy przez rzeki. Po grubym lodzie przejeżdżała pięciokonna kareta, po cieńszym dawały radę sanie. Latem pozostawały brody, mosty albo promy. Do jazdy po lodzie, jak to opisał Wincenty Pol podczas wyprawy na zamarznięty Bałtyk ${ }^{15}$, konie podkuwano specjalnymi podkowami z antypoślizgowymi ostrymi „ocelami”.

Osobną rzeczą były przeprawy wojsk przez zamarznięte rzeki podczas wojen. Berezyna w dniach słynnej bitwy z 1812 roku sprzyjała Rosjanom. Mimo listopada zdążyła zamarznąć, a w momencie, gdy znalazła się nad nią armia Napoleona, lód puścił, powstała kra, utrudniająca budowę mostów, co na przebieg bitwy miało decydujący wpływ.

Podobnie zachowywała się Wisła zimą 1831 roku, uniemożliwiając armii rosyjskiej atak na powstańczą Warszawę. Niemcewicz w tym czasie pilnie śledził jej rozmarzanie i zamarzanie, nie pozwalające ani na przejście z armatami po lodzie, ani na konstrukcję pontonowego mostu, na który Rosjanie rozbierali okoliczne wiejskie zabudowania ku rozpaczy mieszkańców. „Wisła sprawuje się wybornie - pisał w dzienniku 24 lutego - ani puszcza, ani dość mocna, by Moskale przez nią z działami przejść mogli”"

Trwał ten stan jeszcze przez miesiąc bez mała.

Na tym zakończmy nasz pobieżny przegląd skomplikowanych zimowych realiów doby romantyzmu i powróćmy do literatury. A dokładniej do dwóch

13 E. Felińska, Pamiętniki z życia, t. 3, Wilno 1856, s. 160.

14 Taż, Pamiętniki z życia, Seria 2, t. 1, s. 150 i n.

15 Zob. W. Pol, Na lodach, na wyspie, na groblach. Trzy obrazki znad Bałtyku, wstęp J. Bachórz, Gdańsk 1989.

16 J.U. Niemcewicz, Pamiętniki z 1830-1831 roku, s. 74. 
utworów Mickiewicza, Zimy miejskiej i Ustępu III części Dziadów, które $\mathrm{w}$ świetle tego, co zostało dotąd powiedziane, ukazują nowe, niespodziewane znaczenia. Ciekawe to utwory, zaprzeczające jakby omówionym właśnie różnym narodowym zimowym stereotypom. Debiutancki wiersz Mickiewicza głosi pochwałę tej pory roku w wyszukanym stylu, à la Trembecki. Gdyby nie wymieniona tam rzeka Wilia, mógłby w równym stopniu dotyczyć petersburskiego złotego młodzieńca, szukającego rozrywek w mieście. Na przykład Gawriił Dzierżawin, którego twórczość Mickiewicz poznał na lekcjach literatury rosyjskiej, napisał podobną z ducha żartobliwą odę Желание зимы (Oczekiwanie na zimę), mieszczącą się w nurcie ustanawiającym symboliczną zimową tożsamość rosyjską. Jeśli sobie ten fakt uświadomimy, łatwiejsza będzie odpowiedź na pytanie od lat zajmujące interpretatorów - czy Zima miejska jest satyrą? Trudno sobie raczej wyobrazić, że młody Mickiewicz, właśnie organizujący z kolegami Towarzystwo Filomatów, mające kształtować obyczaje młodzieży poprzez krzewienie nauki, tworzy swój wiersz bez satyrycznego podtekstu - nawet jeśli to jest tylko wyjątkowo udane ćwiczenie stylistyczne, jakich wiele dostarczał profesorowi Leonowi Borowskiemu do oceny. W dodatku pisze swój pochwalny wiersz o zimie pięć zaledwie lat po pamiętnym odwrocie Napoleona przez Litwę. A co więcej, wkrótce go drukuje pod własnym imieniem i nazwiskiem. Wszystko to świadczy raczej o krytycznej intencji i dystansie autora wobec podmiotu lirycznego. Niemniej jednak niejasność przesłania wiersza istnieje, choćby dlatego, że jego realia, ukryte pod kunsztownymi metaforami, są bardzo prawdziwe i przekonujące. Każdy z ówczesnych czytelników przecież wolał cicho sunące zaśnieżoną ulicą sanie niż hałaśliwy turkot kopyt i kołowych zaprzęgów toczących się po bruku - gdy koła nie bywały jeszcze ogumione. Każdy wolał łatwą drogę po ubitym śniegu niż uwięzienie w wiejskim domu, gdy jesienne deszcze tworzyły nieprzejezdne bajora na błotnych gościńcach. Nie każdego wprawdzie było stać na kosztowne rozrywki - ale działały one na rozmarzoną wyobraźnię i mniej zamożnej młodzieży. Może właśnie z powodu tej nierozstrzygniętej sprzeczności między dydaktycznym zamiarem, a siłą poezji, niwelującą ideowe przesłanie, Mickiewicz nigdy za życia nie przedrukował tego wiersza.

W Ustępie z kolei, (przede wszystkim chodzi o Drogę do Rosji, Przedmieścia stolicy i Petersburg) poeta uczynił z zimy oręż skierowany przeciwko carskiej despotii. Uderzył prosto w rosyjski mit zimowej potęgi Północy, propagowany w Europie i samym cesarstwie. W Drodze do Rosji pokazał wytyczone przez cara szlaki szybkiej komunikacji, służące wyłącznie jego urzędnikom, a nie obywatelom, istniejące jakby poza cywilizacją (pisze o nich także, jako bezużytecznych dla ludności, Ewa Felińska). W Przedmieściach stolicy egzotyczne, 
wzniesione ogromnym kosztem pałacyki i rzeźby Carskiego Sioła, przysypane śniegiem, przykryte słomą - równie groteskowe jak wyobrażony przez Odyńca widok sanek na Kapitolu - ujawniły pokraczny efekt rosyjskiego dążenia do europeizacji. Mamy tutaj parodię panegirycznego stylu Dzierżawina, ośmieszającą cywilizacyjne wysiłki satrapy ${ }^{17}$. W Petersburgu natomiast zima jest zaprzeczeniem tego, co Mickiewicz chwalił w Zimie miejskiej: mróz nie wyzwala aktywizmu, zabawy, radości i zdrowia, a elita spaceruje po Newskim nie dla przyjemności, lecz dla dopełnienia rytuału złożenia pokłonu carowi.

Tu ludzie biegą, każdego mróz goni,

Żaden nie stanie, nie patrzy, nie gada;

Każdego oczy zmrużone, twarz blada,

Każdy trze ręce i zębami dzwoni,

$[\ldots \ldots \ldots \ldots \ldots \ldots \ldots \ldots \ldots \ldots \ldots \ldots \ldots . .$.

Niejeden kaszlem suchotniczym stęknie,

A przecież mówi: „Jak tam chodzić pięknie!”18

Jednym słowem, przedstawiona w Ustępie zima kompromituje stolicę potęgi Północy wbrew temu, co chcieliby o sobie myśleć sami jej rodowici mieszkańcy, wbrew głoszonej w poezji rosyjskiej idealizacji tej pory roku ${ }^{19}$. Ujawnia śmiertelne zmrożenie i ponure absurdy carskiego samodzierżawia, a nie młodzieńczą witalność czy cywilizacyjną energię Rosjan aspirujących do Europy.

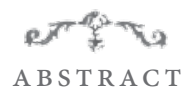

\section{Winter and Romantic Authors}

The article discusses civilisational aspects of western European, Polish and Russian winters in personal accounts (diaries, letters, and memoirs) of Polish Romantic authors. It illustrates how climactic differences influence the perception of cultural differences. The problems explored in the article form a new context for the interpretation of Adam Mickiewicz's great works: City Winter (Zima miejska) and Passage of Forefather's Eve. Part III (Dziadów części III Ustęp).

KEYWOR D S

Adam Mickiewicz, winter, civilisation, Romanticism, cultural differences

17 Więcej na ten temat zob. M. Zielińska, Polacy, Rosjanie, romantyzm, Warszawa 1998, s. $71-125$.

18 A. Mickiewicz, Dziadów części III Ustęp, w: tegoż, Dzieła. Wydanie Rocznicowe, t. 3: Wiersze, oprac. Z. Stefanowska, Warszawa 1999, s. 277-278.

19 O uwewnętrznieniu i udomowieniu zimy w rosyjskiej poezji przełomu XVIII i XIX wieku zob. O. Boele, dz. cyt., s. 91 i n. 